\title{
MID-TERM EVALUATION OF THE NRECA CENTRAL AMERICA RURAL ELECTRIFICATION SUPPORT PROGRAM (CARES)
}

\author{
Robert D. Perlack \\ H. G. (Mike) Jones \\ Oak Ridge Associated Universities \\ Albert Garcia, III \\ T'exas A \& M University \\ Ing. Edgar Flores, \\ Consultant, Guatemala \\ Date Published: September 1990 \\ Prepared for the \\ Regional Office for Central America and Panama \\ U.S. Agency for International Development \\ under Interagency Agreement Number 16.37-1637-A1
}

Prepared by the

OAK RIDGE NATIONAL LABORATORY

Oak Ridge, Tonnessec 37831-6205

operated by

MARTIN MARIETTA ENERGY SYSTEMS, INC.

for the

U.S. DEPARTMENT OF ENERGY

under contract No. DE-AC(05-84OR2140) 


\section{ACKNOWLEDGEMENTS'}

The cvaluation team would like to thank Mr. Mario Funcs for direction and support, as well as the staff of CARES (Jim Lay, Ron Orozeo, Ross Turner and Ivan Azurdia) for their professional inputs and spending considerable time and attention during our visit. The logistical support of NRECA Administrative Assistant Vivian Villalta, and secretaries Ana Maritza Perez and Evelyn M. Giron was also essential and is very much appreciated. The many USAID Mission energy or engineering staff members, including Roberto Figueroa, Arthur Villanueva, Heriberto Rodriques, and Hugo Elvir also contributed substantially to our effectiveness. Likewise, INDE and EEGSA and Ministry of Mines and Energy officials in Guatemala, ENEE officials in Honduras, Ministry of Energy and Mines, Cooperative officials, and ICE in Costa Rica, CEL in El Salvador, and BEB officials in Belize were also open and generous with their time and advice. 
TABLE OF CONTENTS

ACKNOWLEDGEMENTS $\ldots \ldots \ldots \ldots \ldots \ldots \ldots \ldots \ldots \ldots \ldots \ldots \ldots$ iii

ABSTRACT $\ldots \ldots \ldots \ldots \ldots \ldots \ldots \ldots \ldots \ldots \ldots \ldots \ldots \ldots \ldots \ldots \ldots \ldots \ldots \ldots$

EXECUTIVE SUMMARY OF FINDINGS AND RECOMMENDATIONS $\ldots \ldots \ldots \ldots \ldots$ ix

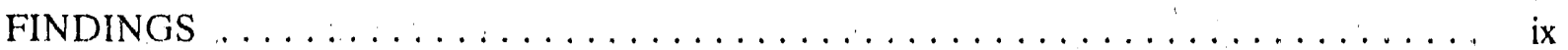

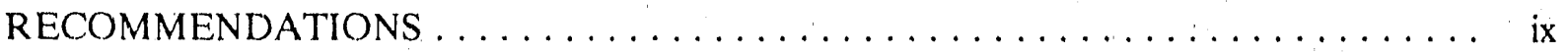

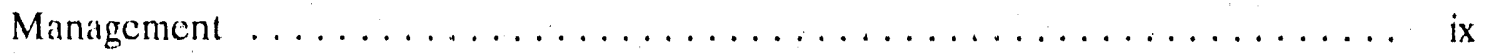

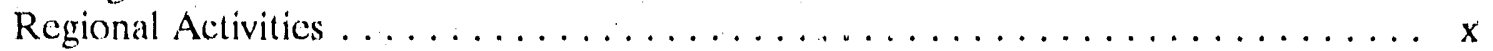

Country Activities . . . . . . . . . . . . . . . . . .

1. INTRODUCTION $\ldots \ldots \ldots \ldots \ldots \ldots \ldots \ldots \ldots \ldots \ldots \ldots \ldots \ldots \ldots \ldots \ldots \ldots \ldots$

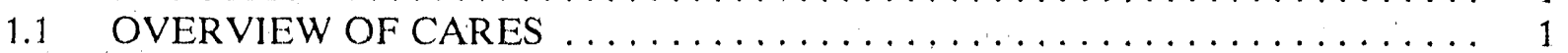

1.2 RELATIONSHIP TO CONCURRENT ELECTRIFICATION PROGRAMS . . . 1

2. CARES PROGRAM ADMINISTRATION AND MANAGEMENT $\ldots \ldots \ldots \ldots \ldots \ldots$

2.1 PROGRAM FUNDING AND SCHEDULE $\ldots \ldots \ldots \ldots \ldots \ldots \ldots \ldots \ldots$

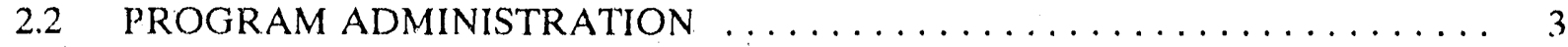

2.3 PROGRAM MANAGEMENT $\ldots \ldots \ldots \ldots \ldots \ldots \ldots \ldots \ldots \ldots \ldots$

2.4 CARES PROGRAM IMPACT INDICATORS $\ldots \ldots \ldots \ldots \ldots \ldots \ldots \ldots \ldots$

3. CARES PROGRAM ACTIVITIES $\ldots \ldots \ldots \ldots \ldots \ldots \ldots \ldots \ldots \ldots \ldots \ldots$

3.1 REGIONAL ACTIVITIES $\ldots \ldots \ldots \ldots \ldots \ldots \ldots \ldots \ldots \ldots \ldots$

3.1 .1 Demand Assessment Model (DAM) . . . . . . . . . . . . . 9

3.1.2 Alternative Financing and Decentralization $\ldots \ldots \ldots \ldots \ldots \ldots \ldots$. $\ldots \ldots$

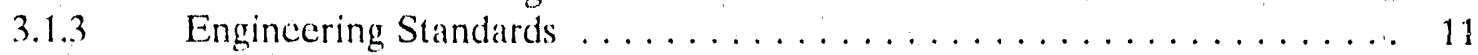

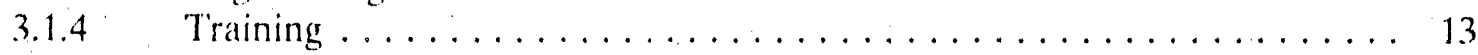

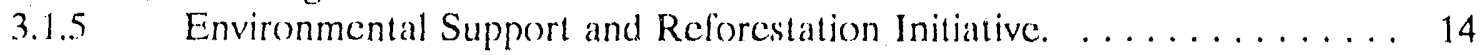

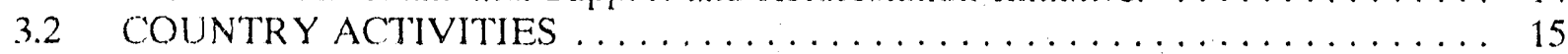

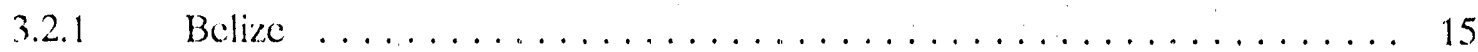

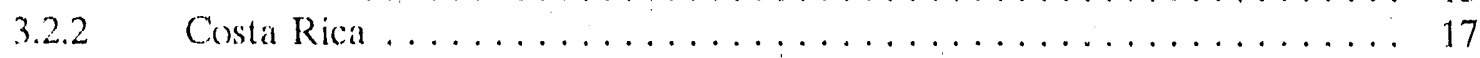

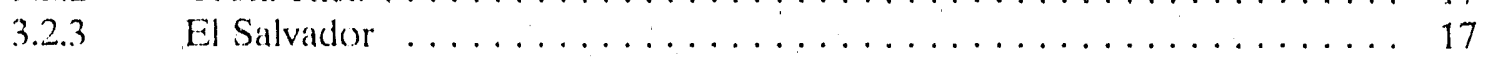

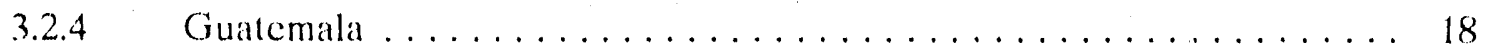

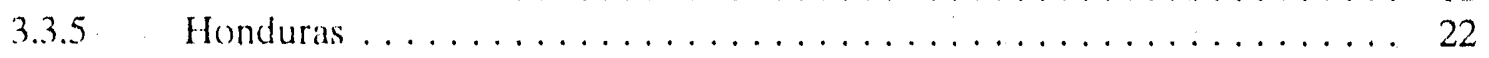

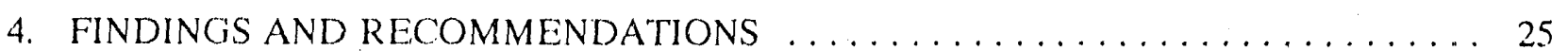

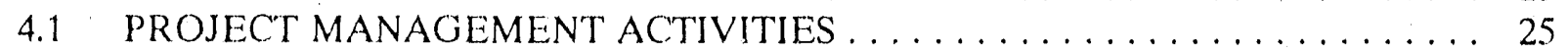

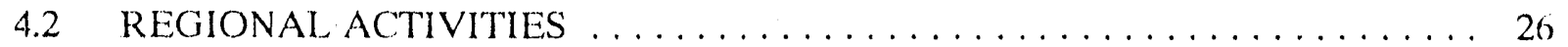

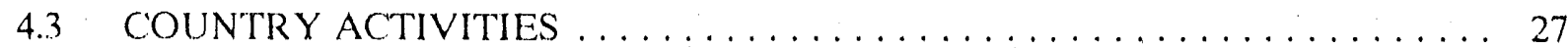

APPENDIX 1: LIST OF PERSONS INTERVIEWED AND SITES VISITED $\ldots \ldots \ldots \ldots 29$

APPENDIX 2: LIST OF DOCUMENTS REVIEWED $\ldots \ldots \ldots \ldots \ldots \ldots \ldots \ldots$

APPENDIX 3: STATEMENT OF WORK FOR EVALUATION TEAM $\ldots \ldots \ldots \ldots$ 


\begin{abstract}
Oak Ridge National Linhratory was requested by the Regional Office for Central America and Panama to conduct a mid-term evaluation of the Cares Project, which is being implemented by the National Rural Electric Cooperative Association. This evaluation was conducted over a three week period by a four person team. Overall, the project has had numerous successes and is highly valued by local counterpart utilities and USAID Missions. Notwithstanding the significant results of the project, changes can be made in certain operating procedures and in the direction of some programmatic activities that can lead to an even more effective project.
\end{abstract}




\section{EXECUTIVE SUMMARY OF FINDINGS AND RECOMMENDATIONS}

\section{FINDINGS}

The CARES Project is highly valued by Central American utilities and USAID Missions. There have been numerous and notable successes, including:

- adoption of new distribution standards,

- broad acceptance of productive uses promotion,

- use of the demand assessment model in Guatemala and El Salvador,

- cooperative and private policy persuasion (Belize, Chile, and Costa Rica scminars and observational tours),

- El Salvador program design,

- technical training activities, and

- the creation of CONELECTRICAS in Costa Rica.

Despite these successes, the project is too broad geographically and in scope for existing professional staff. In the absence of more professional staff (particularly an economist), there is a need to focus on core programmatic activities -- policy dialogue and institutional reform, enhancement of operational efficiency, training, least-cost rural electric system design, and productive uses of electricity.

The CARES Project staff are productive, conscientious, and competent. However, refinements in planning (workplan, annual report, impact indicators, training) and financial reporting can be made that would serve to make : aff more effective.

A number of new initiatives ar being added without adequate consideration of impacts on core staff time. The evaluation team lelieves that full-time staff (preferably local hires) are needed for Costa Rica and Belize, if the program is augmented, and in Honduras to effectively implement planned activities during the next two years. The Honduras program offers a major opportunity for application of DAM model, productive uses, and standards. The Honduras irrigation tariff study (not yet completed) should be redirected and receive priority attention.

CARES has taken a commendable initiative to accelerate the PER-III productive uses component. Although not a direct CARES project concern, there is a potential problem with PERIII USAID split management and INDE AITEC/FUNDAP interaction.

\section{RECOMMENDATIONS}

\section{Management}

Financial reporting. Clarification of the content, routing and schedule for financial reporting is needed.

ROCAP monitoring. ROCAP should maintain more operating familiarity with the project, including monthly bricfings and occasional travel to CARES country project sites with project staff. 
Project monitoring. Project monitoring should be systematized with the Annual and SemiAnnual report carefully reviewed by ORNL. There should be a joint review meeting held among ROCAP, ORNL and NRECA staff at least every six months.

Impact Indicators. Specialist assistance (not project staff) should be sought to develop and finalize impact indicators. There should also be an attempt to document the results from training.

\section{Regional Activitics}

Training. There is a need for a detailed training plan and schedule, with possible rescoping of U.S. based training. Training in productive uses should be increased.

Engincering Standards and Technical Activitics. CARES staff is correct in decmphasizing transformer evaluation and local manufacturing of pole hardware. More responsibility for the surplus equipment program should be shifted to Washington.

Demand Assessment. The Project should pursue the use of the DAM in the PER-III site selection process, especially as it relates to initial screening. Attempts should be made to synthesize the key results of this study for other country applications. More structured sensitivity analyses should be undertaken to gauge the robustness of estimated parameters and to isolate the other key system parameters in hopes of focusing data collection efforts. NRECA staff should consider publication in peer-reviewed development or energy journals for more professional recognition.

Reforestation Initiative. The CARES staff should avoid taking on responsibilities in reforestation that would have the effect of diluting already critical management resources. Any activities in reforestation should be done in a complimentary role to wood pole production or be related to other aspects of the project. For example, CARES staff may want to consider conducting studies to evaluate the potential impacts of deforestation on the siltation of reservoirs and the loss of capacity.

\section{Country Activitics}

Belize. The BREMA proposal should be pursued. However, additional consideration should be given to dispersed and renewable energy generation for servicing more remote village loads.

El Salvador. There are no specific recommendations suggested for El Salvador activities. activitics.

Costa Rica. It is recommended that a full-time stafl person be hired to oversee Costa Rican

Guatemala. The productive uses initiatives at INDE should be augmented by working with credit and assistance groups that serve larger microenterprises. The overall CARES regional surport function and direct INDE support activity of NRECA requires a permanent local-hire specialist. USAID's split management responsibility for the PER-III project may contribute to this problem -reconsider the split responsibility or ensure vigorous management oversight and coordination. 
Honduras. CARES staff should implement the comprehensive demand assessment, productive uses and standards activities in Honduras consistent with the capacity of ENEE to absorb assistance. The hiring of a full-time staff person for Honduras should be considered. A revised irrigation tariff study report should emphasize the methodology as well as the constraints and institutional aspects of promoting off-peak energy use. 


\section{INTRODUCTION}

The Central America Rural Electrification Support (CARES) program is sponsored by the U.S. Agency for International Development (USAID) through its Regional Oflice for Central America and Panama (ROCAP), and is being implemented by the National Rural Electric Cooperative Association (NRECA). Oak Ridge National Laboratory (ORNL) was requested by ROCAP to provide monitoring assistance on a regular basis and in a spirit of collaboration with NRECA. In this capacity, selected activitics have been monitored by ORNL on behalf of ROCAP for progress and quality assurance in a fashion similar to that of formal evaluation, but for a much more limited and focused set of activities. The Mid-Term Evaluation represents a more formal and thorough project review, the purpose of which is to comprehensively assess progress to date, to review the scope of activities undertaken and their current relevancy to rural electrification issues, to highlight activities that may require more focused attention, and to suggest mid-course corrections if necessary. This evaluation was completed over a three week period (two wecks in-country) by a four person tcam.

\subsection{OVERVIEW OF CARES}

Rural electrification in Central America has been slow to develop. Faced with dispersed loads, geographic barriers, and slowly developing economies, rural electrification can be characterized as having achieved mixed results. Additionally, power systems in several countries in Central America are entering a period of unprecedented uncertainty. Capital constraints, a changing policy environment, and pressure to rapidly expand infrastructure to meet projected demands are presenting these institutions with difficult challenges. Rural demand growth, through line extension and increases in economic activity, will clearly add financial pressures on utilities, and bring into question the quality of service to these expanding load centers.

To address these issues, the CARES Program was initiated in 1987. CARES has as its objectives to stimulate dialogue on policy and institutiona! reform, to enhance operational efficiency, to promote least-cost rural electric system design, and to encourage the productive uses of electricity. The CARES Program is orgarized into both regional and country specific activities. Regional project activities have included the development of the demand assessment model, the promotion of productive uses, the development of enginecring standards, training (management, operations and technical) programs, alternative financing and decentralization, and environmental support. The five CARES Program countrics (Belize, Costa Rica, El Salvador, Guatemala, and Honduras) have had (or at least planned) activities related to demand assessment, productive uses, standards, and training. In addition, there have been country specific studies, such as the assessment of isolated power in Belize, the support of electric cooperatives in Costa Rica, program integration and productive uses demonstrations in El Salvador, municipal utility assistance in Guatemala, and an irrigation rate study in Honduras.

\subsection{RELATIONSHIP TO CCNCURRENT ELECTRIFICATION PROGRAMS}

CARES has been successful in leveraging its programmatic efforts with similar projects in other countries. Most of the concurrent projects were initiated by local USAID Missions and have some overlap with the stated objectives of CARES. A good example of the suceess in this area is the San Lorenzo Hydroelectrio project in Costa Rica. The local cooperatives have joined to form a generation and transmission eooperative (CONELECTRICAS) and have selected a $16 \mathrm{MW}$ hydro- 
electric site as their first project. This project has been well coordinated among other agencies with funding and other participation by the local USAID Mission. This activity is also part of a national initiative by the current government. The new government has pledged its support of CONELECTRICAS and the hydro project.

In Guatemala, the USAID Mission has funded a series of rural electrification projects through the Instituto Nacional de Electrificacion (INDE). The CARES project has provided technical leadership and support to these various initiatives, the latest being PER-III (Proyectos de Electificacion Rural). The USAID Mission has carefully determined those areas of overlapping interest and has coordinated directly with the CARES Staff. This cooperation has had the beneficial effect of presenting a common face to INDE and the Ministry of Energy in Guatemala.

NRECA has done an exceptional job of coordinating and assisting related activities of other USAID projects in other Central American countries. For example, in El Salvador the CARES project assisted the Mission to prepare a major new project; CARES staff were instrumental in preparation of the PER-III project design in Guatemala; and both USAID and the World Bank have sought to use the demand assessment and productive use methodology developed by NRECA staff for application in Bolivia and elsewhere. These resulis can be interpreted as an indicator of project success and credibility. 


\section{CARES PROGRAM ADMINISTRATION AND MANAGEMENT}

This chapter reviews issues relaled to program funding, reporting, ROCAP administration, and NRECA management. Also presented is a discussion of CARES program impact indicators.

\subsection{PROGRAM FUNDING AND SCHEDULE}

Project financial reports consist of two types: (1) the official drawdown report, which is the NRECA invoice to USAID of (quarterly expenditure, and (2) the quarterly program monitoring report to ROCAP. Delays in quarterly program monitoring reports have occurred in the past, and ROCAP has expressed concern regarding timing and appropriate report content. However, a brief review of recent drawdown reports dises not appear to indicate a timeliness problem. For example, the October-December 1989 drawdown report was submitted to USAID/Washington on October 30th, and received on November 27th in Guatemala.

Program expenditure reports have been delayed. NRECA has reported that it now has resolved internal constraints that had affected the timeliness of the project monitoring reports, and is prepared to resume submittal on a quarterly basis. The content of these reports should also be evaluated periodically so that they continue to meet current ROCAP needs. In any event, these financial reports should serve a definite management purpose and not be an excessive burden to NRECA. A suggested financial reporting scheme, based on discussions with ROCAP, NRECA headquarters and CARES management, should contain the following cost categories: total budgeted expenditures, total project expenditures to date, remaining funds, annual budget, and yearly expenditures to date. The level of detail for each category should include salaries, fringes, overhead, travel, allowances, other direct costs, and equipment and supplies.

In addition, there should be a semi-annual report of staff effort by workplan category with a brief notation of any milestones (specific milestones as contained in annual workplan) achieved by activity. This information should be sufficient for monitoring by ROCAP, and provide the information base for a semi-annual monitoring review meeting. Quarterly monitoring reporting of this type would not appear to be any burden for staff, as this information is already compiled. Inclusion of detailed financial information on each activity in monitoring reports, on the other hand, appears unnecessary. The level of elfort recommended should contain only the most timely and essential data. Detailed financial information would probably only. "muddy the waters," and necessarily be incomplete and difficult to interpret at more frequent intervals. Annual review of finances at the activity level would have greater value to track rates of expenditure and country allocations.

\subsection{PROGRAM ADMINISTRATION}

The CARES Project is administered by the ROCAP oflice in Guatemala City. The project manager during most of the review period was Mr. Carl Duisberg, who was involved in the conception of the project and the initial goal setting. The new ROCAP project manager, Mr. Mario Funes, should continue to maintain as much day to day operating familiarity with the project as possible and consider travel to CARES country project sites with project staff in order to fully exereise his monitoring and approval responsibilities. 
Recent initiatives by Mr. Funes in the area of impact indicators has highlighted an area not adequately addressed in the past. This step is a positive development to articulate specific goals and accomplishments. (See below.)

Overall, communication and coordination among the ROCAP staff and the local USAID Missions are sound, especially in Guatcalala and Costa Rica. The view that the local USAID Missions are the primary clients has helped to ensure solid local decisions.

\subsection{PROGRAM MANAGEMENT}

The Annual Workplan is a time consuming document to prepare. Moreover, in its present format, the plan does not establish a schedule for staff activity, or provide an adequate set of milestones and indicators of progress that can be easily monitored: The format needs to be revised to allow the plan to be presented simply and with elarity, relating planned activities to the CARES Project mandate, as well as to specific planned accomplishments.

The primary purpose of the Annual Workplan should be to serve as a working strategic plan for the NRECA Staff during the upcoming year. A secondary, but still important, purpose of the Annual Workplan is to inform ROCAP of the planned activities in each country and how they relate to overall objectives. It should be organized in such a manner as to reflect the original four objectives of the project, the planlied activities of the four professionals, and country specific objectives that can be measured. Exclusion or placement in an Appendix completed activities and activities planned for subsequent years would simplify the presentation substantially.

A revised Arınual Workplan format should:

1. Eliminate detailed descriptions of completed activities, and activities for which no effort is anticipated in the plan year. A summary table should be included in an appendix with all activities and planned year of execution.

2. Revise task descriptions to rellect current agreed activity between CAPES, ROCAP and counter part country institutions.

3. Include several clearly defined milestones for each major activity (e.g. Guatemala Productive Uses) by which progress and quality of output can be evaluated. Ideally, each milestone would show some antecedent relationship among activitics. A critical path chart without excessive attention to the time analysis would accomplish this need.

4. In addition to aggregate activity level budgets, staffing levels in terms of permanent technical specialists and consultant person-months should be provided. 
A revised Annual Report format should incorporate the following changes (in addition to those in ROCAP Memorandum of December 4, 1989 from Carl Duisberg to James Lay):

1. Include an expanded listing and narrative of major outputs (consistent with impact indicators discussed below in this report).

2. Provide a table listing the stalf-loading cumulatively and for the reporting period, for all major activity areas.

It is suggested that project monitoring be systematized with the Annual and Semi-Annual report carefully reviewed by ORNL. Thereafter, a joint review meeting should be held with the ROCAP project manager, ORNL and NRECA every six months. Future project evaluations should continue to utilize a local counter part consultant to facilitate the review and to provide insight into local conditions, policies and prioritics.

The significant number of new Initiatives proposed over time by the country utilities and/or USAID Missions underseores the need for a systematic review of proposed changes to CARES activities. At a minimum, new initiatives should be clearly highlighted in the Annual Workplan, with specific discussion and justification presented (ROCAP should be asked for prior approval on activities proposed outside this cycle), before shilting priorities or reallocating funds. It is particularly important to recognize that with limited lunds, all new activities result in the dilution of existing staff efforts and the reduction in scope and probably delay in programmed work.

\subsection{CARES PROGRAM IMPACT INDICATORS}

The development of impact indicators is behind schedule. Consultant Charles Weaver has presented a draft proposal, but these recommendations do not add significantly to the recommended changes suggested by Ross Turner in his Memorandum of December 1, 1989. In general, this area has posed continuing difficulty for CARES staff and concern to ROCAP. The task has proven to be substantially more difficult than originally envisioned in the project design and as elaborated in the project log frame.

In general, three levels of project indicators are needed. First, at the highest level of project evaluation, a few ultimate project indicators are required. These broad-based indicators of project suceess and effectiveness, however, are not appropriate for ongoing monitoring. Therefore, a second level of result indicators are needed to allow for ongoing evaluation of the major activities, such as standards, productive uses, demand assessment. These indicators allow for assessment of project performanec as well as assessment of the individual activity components (e.g., effectiveness of credit programs, different methods of productive uses promotion, etc.). In addition, a third level of indicators are needed for monitoring progress for particular project activities (e.g., training -- number of trainees, finanees -- expenditure levels versus targets). 'These lowest-level indicators should tic-in closely to program milestones by activity. Activities must be themselves disaggregated by country, and be closely related to the four overall program objectives -- institutional reform, operational efficiency improvement, least-cost rural electric system design, and productive uses promotion.

The following ultimate project impact indicators are suggested. These impact indicators are for evaluating the overall suceess of the CARES Program and are not appropriate for on-going monitoring. 
1. Productive Uses Ratio (Fraction of Productive Uses Before and After). These benefits have been defined as energy cost savings (i.e., less expensive electricity cubstituting for diesel, gasoline, or other fuel in a productive use); increased production as a result of having a less-expensive power source; and quality improvements that can be attributed to the use of electric equipment. In addition, this productive uses ratio should be supplemented with information on the costs and benefits of generating productive uses.

2. Reduced Costs of Rural Electrification Construction. This indicator should relate to all utilities that the project targets to mersure program effectiveness as well as actual savings. It is further suggested that the project use conservative percentage output targets. Final results should not be arbitrarily judged "below expectations" and therefore poor, e.g. if only $10 \%$ versus $20 \%$ savings are achieved, as $10 \%$ still repres ants a substantial achievement. Finally, supplying estimated savings and total costs at the end of the project will be both more impressive and useful for judging the cost-effectiveness of this activity.

3. Investment in Rural Power. This indicator would be suitable if results are reported in terms of the population receiving electricity as a result of project intervention. An indication of the number of $\mathrm{MW}$ installed, new lines constructed and rebuilt, and number of actual new projects would also be suitable indicators of the actual results. Simply using an aggregate dollar figure as proposed can be misleading, since it does not indicate the type of investment, for example number of persons served and whether high versus low priority rural areas aie servidd.

4. Rural Population Receiving Electricity (where CARES intervention was an essential ingredient). This indicator should be provided country by country, and be related to a target that the project establishes based on expectations from CARES programs.

5. Training. There should an attempt to document the results from training. This documentation could take the form of an attendee report on the results of training in terms of direct application of lessons learned. Follow-up reports on implemented improvements related to training at annual intervals would also be worthwhile. Annual or periodic follow-up to monitor any improvements related to training is also desirable. These reports would substantially contribute to the ability to document results.

A consideration still not addressed in the above indicators is the institutional development aspect of the project, and the replicability and sustainability of project interventions. The log frame type "Objectively Verifiable Indicators", (e.g. "firmly established rural electrification division in minimum of three of the six countries,") is still needed for institutional development verification.

It is recommended that specialist assistance (not project staff) be sought to refine and finalize the three levels of needed indicators. The project is in its third year, entirely too late for these issues to remain outstanding. A plan for the compilation of needed data and staffing requirements to meet this need should be an additional part of this task. 
Finally, in looking ahead to the end of project evaluation, preparation would be greatly facilitated if there is a short overview for each program area. This overview should include: major accomplishments by task area (milestones reached); descriptions of current tasks according to operational terms of reference (as opposed to summary terms in workplan); allocations of staff and consultant levels of effort by task area (for period since last reviews); summaries of travel by staff members; current budgetary information; problems and/or areas needing attention; brief descriptions of contacts involved with the project and organization charts for major counterpart organizations; and lists of training courses given with the number and position of attendees by country and organization. 


\section{CARES PROGRAM ACTIVITIES}

\subsection{REGIONAL ACTIVITIES}

\subsubsection{Demand Assessment Model (DAM)}

The demand assessment model was completed as a regional activity in FY88 with refinements to be completed under country specific applications (see country activities). The model was developed to help utility planners screen and prioritize candidate projects for electrification and to provide a framework for assessing the financial and economic viability (benefits and costs) of projects. A particular strength of the model is its ability to explicitly quantify the financial and economic benefits of productive uses of electricity. The model provides a logical framework using many preprogrammed calculation routines to structure data collection efforts, to evaluate socioeconomic factors on the ranking of projects, and to formalize the decision making process. Recent interest in applying the model by the World Bank in Bolivia and elsewhere reflects on the credibility of the model.

The model requires information on demographics, line extension costs, number of connections, and other general information, such as applications for service and for preliminary screening analyses. Information requirements become much more intensive once candidate sites have been selected for more in-depth, site-specific analyses. For example, site-specific analyses require information on tariff schedules, electricity conversion rates, gencration costs distribution site characteristics and costs, residential electricity uses, and, most important, the identification and estimation of electricity demand for productive uses. Much of this model data must be collected on site. However, the model does contain default values, which are meant to be indicative and can be easily changed at the discretion of the DAM user. Input data ranges for productive use activities and alternative demand growth parameters are also accounted for in the model.

The model documentation and ancillary reports were reviewed. In general, the documentation was found to be satisfactory, although one has to consult many reports to get the specifics related to major assumptions and methodology. In general, the approach and key assumptions used in the model are well thought-out and appropriate for rationalizing rural electrification decisions. The methodology focuses on the rural characteristics that have plagued past electrification efforts -dispersed consumption, low demand growth, and high connection costs.

A key aspect of the model is the explicit consideration of productive use benefits. These benefits have heen defined as energy cost savings (i.e., less expensive electricity substituting for diesel, gasoline, or other fuel in a productive use); increased production as a result of having a less-expensive power source; and quality improvements that can be attributed to the use of electric equipment. For example, the demand for local crafts may actually increase because of higher product quality.

The estimation of benefits in the DAM is relatively straightforward. Residential benefits take the form of sales revenue from the use of electricity and cost savings by foregone expenditures for kerosene and batteries. However, benefits associated with higher quality light, modernization and use of appliances, and greater convenience are not formerly estimated. A similar approach is used in estimating productive use benefits. Sales revenue from the additional energy used and cost savings resulting from the replacement of diesel motors. The DAM evaluates cost savings using existing nonelectric equipment as a base. For new productive uses, the use of existing equipment as base may 
underestimate benefits. However, in the absence of the project it cannot be said with certainty that productive uses would not have developed. The method of estimation of benefits from new productive uses is a conservative measure inut an acceptable one considering that these uses may have developed without the project.

In sum, the approach taken by the DAM developers is a good one, recognizing the original intent of the model as a tool for evaluating and selecting sites. This review is in agreement with the original model premise -- to develop a rational and easy to use framework that is consistent with the availability of data and the time required for collection and synthesis. The overall approach taken is rational runsidering the time and manpoyer cost of detail versus the type of decisions to be made. To be sure, the validity of model results depends on the quality and consistency of information entered into the model.

The following recommendations are suggested as country activities. First, training of local utility counterparts in using the model is encouraged as well as early integration of counterpart staff in country specific applications. Second, an attempt should be made to formally calibrate the model when actual field level data are availe ole. Third, a potential weakness of the model may be its data requirements and the need for trained staff to ensure that the model is consistently applied. Attempts shou't be made to understand how productive use activities correlate among countries to sec if data collection efforts might he reduced and made less burdensome. More detailed sensitivity analyses should be conducted to isolate the key system parameters in hopes of focusing data collection efforts. The extensive applicability of the model suggests that it should be more widely disseminated. NRECA staff should consider publication in peer-reviewed development or energy journals for more professional recognition.

\subsubsection{Alternative Financing and Decentralization}

The report of this activity has been combined with Decentralized Project Support and Privatization. The primary emphasis for this activity is from the local governments that lack the capital resources for financing system expansion. Often the privatization efforts will not come from private enterprise but local organizations or volunteer associations (i.e., small town municipal or new coops). The CARES Project has been very productive in this area by fostering communication among the participating countries. The Private Sector-Decentralization seminar hosted by INCAE is one example. The seminar was well-planned, professional, and involved some very frank discussions.

The success of the COOPS in Costa Rica has proven to be an excellent example for the other countries. CARES has been very effective in using the Costa Rican COOPS as a point of departure for discussion with the other countries. This approach appears to be a very successful tactic. The CARES-sponsored seminar on privatization included a trip to COOPESANTOS. The COOPESANTOS trip proved to be the most provocative element of the seminar and convinced many of the public sector leaders of the benefits of decentralized distribution.

As an example, the Government of Honduras has declared privatization their number one priority by enacting a strategic plan. They appear to be the furthest along in determining what kinds of institutional reforms are necessary to remove barriers to private investment. The plan is based on a multi-pronged effort of de-bureaucratization and de-regulation. The goal:: of this initiative are to achieve $90 \%$ electrification in the rural areas and develop new generation capacity. However, an 
excess of personnel that cannot be re-assigned, insufficient internal capital, and general economic conditions of the country may restrain privatization in Honduras.

The single most common barrier to privatization of power is the determination of the purchase price for privately generated electricity. Assisting in the determination of purchase agreements is one area that CARES could provide expertise and have a significant impact on decentralized electrification. Avoided costs for additional production have been defined to be different from the marginal cost of production. Since most of the countries have subsidized rates, a good basis does not exist for stating a clear policy on how pricing structures will be determined. Determination of price is the most critical activity to privatization because investors will want to know what income can be projected in order to calculate a potential return on investment. In general, privatization can often be a very serious and emotional subject because many in the public sector sincerely believe that it may not be in the best interests of the country.

The CARES Project will have an impact in this area if it can place full-time staff in specific countries. It is highly recommended that full-time staff, preferably local nationals, be hired to work in place of short-term consultancies. For example, in Costa Rica a resident staff could help ensure that momentum is not lost and serve as facilitator for the various other CARES initiatives.

New privatization and decentralization activities must be reviewed in light of their potential conflict with already programmed activities. Inclusion of any new work, such as assisting municipal utilities, should only be permitted where it can be shown that existing activities will not suffer. The scarcest asset on the project is full-time staff. There is risk that adding new and small-scale initiatives can affect staff productivity.

\subsubsection{Enginecring Standards}

The engineering standards portion of the CARES project is designed to lower construction costs of single-phase distribution lines, lacilitate local manufacturing of pole-line hardware, encourage productive uses, decrease operating costs and increase operational reliability.

The Regional Workplan Components affected by the engineering standards initiatives are:

- Rural electrification standards

- Transformer evaluation and management

- Local manufacturing of distribution equipment

- Local manufacturing of poles

- Monitoring equipment

- Surplus equiprnent

The Standards Activity was reviewed approximately four months prior to the mid-term evaluation. This review was a detailed assessment of the progress and technical aspects of the activities relating to the components mentioned above. In general, the progress in this area has been exceptional given the institutional momentum that existed prior to the CARES Project. Included in the Standards Activity review was a list of observations and suggestions for CARES staff, which are still applicable. It should be noted that the recommendation for disseminating the computer-aided design software for distribution systems has been completed. 
The new rural electrification standards for Guatemala and El Salvador have been developed and are being implemented. The suceess of the new standards and the demonstrated cost savings have impacted the thinking in Honduras. The new initiatives by the Honduran Government for rural electric cooperatives may provide an opportunity for implementation of a new rural standard.

One of the unanticipated suecesses has been the use of the country specific components as demonstration activities. These activities have resulted in several of the components becoming regional in scope. For example, the Computer-Aided Distribution Design program for El Salvador was completed as a country specific activity. However, computer aided design has been used as a training topic for engineers in other participating countries. Similarly, Honduras is interested in the rural small generation components in Costa Rica and standards activity in Guatemala.

The sub-station metering program in El Salvador is in place and working well. Although this is a local USAID initiative, the program presents an excellent opportunity for operations training in the other countries and should be pursued in much the same way as the computer aided distribution design course.

Transformer cvaluation. During the Standards Technical Review it was suggested that transformer evaluation be deemphasized. This recommendation is still valid. Although this activity has some merit, it should be given a lower priority during the remainder of the project. It may be more advantageous if technical assistance is directed towards management training for better control of non-technical losses.

Surplus Equipment. The surplus equipment program has had a difficult and time consuming start while procedures and contacts were being developed. However, the program is now operating and is proving to be very worthwhile. In the INDE service area, communities proposed for electrification must commit 30 percent of the capital cost in advance of construction. In the case of EESGA, cost sharing can be 100 percent of the construction cost. Although the total value of the surplus equipment is not very large, it is counted as part of the village's required financial participation. Thus, the equipment is well-leveraged and not just a benefit to the company. Activity in other countries is limited and probably should remain so until more NRECA personncl are available to assist in the coordination effort.

This program needs to be managed and supported by NRECA in Washington to free the CARES staff from as many of the coordination tasks as possible. The CARES staff should be responsible only for disseminating the inventory and the technical support necessary for selection.

Local Manufacturing. The components for the promotion of local manufacturing can be divided into two parts. The first involves the construction of distribution equipment, principally pole hardware. While this activity may have seemed feasible during the initial study, after two years it is becoming obvious that there is little that can be gained here. Importing raw materials is so difficult and expensive that little basis can be found for pursuing this activity very vigorously. The potential gains are insufficient to warrant much expenditure of precious staff time. It is recommended that this activity be de-emphasized.

The second aspect of the local manufacturing component is in the area of wood pole production and use. The use of wood poles could potentially save a considerable sum of money both in new construction and line maintenance. The COOPS in Costa Rica have served as an effective 
demonstrator of wond pole manufacture. There are still some areas that cause concern among the other utilities. The biggest problems appear to lie in quality control. The CARES stalf is addressing these concerns through regional training programs dealing with quality control and assessment.

The efforts in wood pole technology should be continued but with a well defined perspective as it relates to promoting rural electrification. There already is a wood pole industry in Honduras and Costa Rica, but it is immature in its adoption of lechnology. CARES can have a signilicant impact in two areas: training utility personnel in wood treatment quality assessment and in establishing, a regional standard on the proper production, grading and treating of wood poles.

\subsubsection{Training}

There are three formal training calegories -.. linemen training, utility management training, and operations training. In addition, there are several specilic training areas that are not included in the categories listed above, productive uses, decentralization, standards, assistance to municipals utilities, and demand assessment.

NRECA has defined three verifiable indicators lor assessing the impact of training programs, these are:

- A minimum of 100 linemen trained in a minimum of four countries;

- 25 senior management stalf trained in a minimum of three seminars at INCAE, and up to 25 more trained in the United States from at least four countries; and

- a minimum of 150 enginecers/technicians trained in all phases of distribution operations.

These verifiable indicators do not measure the effectiveness of training. Other indicators such as actual aceomplishments of trainees after courses are needed.

General Training Comments. Plans and schedules for this activity are not adequate. It would be desirable to have a schedule of seminars and courses for the whole program duration, specified by year and by country. Without these plans it is difficult to follow the performance and accomplishment of the activity and to determine if the activities are heading towards meeting the final objectives.

In the absence of a well-delined training plan and without a clear understanding of the CARES Project, ulilities will be unable to take full advantage of training activities. One example of this is that utilities prepare their budgets for the following year, six, eight or ten months before, and if they do not know in advanee the training opportunitics, they will not be able to budget per diems and other expenses. It is strongly recommended that prio ily be given to this area, as it has a great impact on rural clectrilication.

Additional on-the-job training in the U.S. with member cooperatives might be extremely helpful where intensive training and hands-on experience is desirable (c.g., computerization of billing, operations management, etc.). The project would also do well to ofler courses to meet specialized needs and to augment support l'or attendance at appropriate prolessional meetings. Activities of this 
type tend $t o$ raise prol'cssionulism and opportunity in the utility industry and address the problem of low salaries and the need for other ineentives to retain eornpetent personnel.

Management Training. NRECA has two main management training courses .. the Organization, Management and Operations of Electric Utilities Course (OMO Course) and the Management Planning and Control Course (INCAE Course). The OMO course has been revised over the years and it is now oriented to mid-management and senior administrative utility managers. The course covers such topies as technical standards and system design concepts, institutional issues affecting jerformance, management and problem solving, operating systems in utilities, measuring and cvaluating utility performance, and planning and budgeting. The type of material covered and the importanee of management in general to regional utilities indicale that the course serves a valuable function. The degree lo which this course versus other training activities should receive more or less financial support is unclear without a training plan and strategy. The INCAE training course has generally been fivorably received and appears very much oriented toward distribution utilities.

While not under the direct control of NRECA, the selection of eourse participants should be more carcfully checked. In public utilitics, there is a large turnover of people, cspecially people in management positions. Courses should select more than one person and from different management levels to assure knowledge will remein in the utility.

Operations Training. Operations training activities deal with design, construction and maintenance. NRECA is currently undertaking an audit of utility's needs in the area of operations. Unfortunately, this audit should have been completed during the first year of the program and not after two years of program implementation. This fact explains why there is no program in this training category and why very little has been done. It is imperative that NRECA develop a program or risk not attaining the stated objectives. NRECA should complete their evaluation of utility operations needs, especially in the area of billing, meter reading, and in controlling nontechnical losses.

Lincmen Training. NRECA has an excellent course in lineman training. However, NRECA should recognize that utilities have 10 mobilize men from all over the country. Therefore, it is necessary to set a schedule of activities well in advance to allow utilities to properly respond.

Produr.tive Uses Training. To establish productive uses criteria as an institutional tool, training should be focused towards the whole institution. In Guatemala, planning and rural electrification department personnel are involved in productive uses because these are the areas dealing with demand assessment and site selection. Productive uses training however should be expanded to include commercial department personnel. Productive uses programs in communities already electrified could be initialed in advanee of the PER-III project. Utilitics should be encouraged to start serious talks with government and non-government organizations to set programs in productive uses with existing consumers.

\subsubsection{Environmental Support and Reforestation Initiative.}

This activity is a new initiative linked to ROCAP's growing emphasis on the environment and watershed management. The eonnection with the CARES program is through watershed protection surrounding small hydropower sites and to the regional pole technology and supply enhanecment 
activity. In addition, the activity would solicit NRECA momber contributions for financing minireforestation projects with the goal of miligating sone of the impacts of global warming.

The objective of this activity would be to lessen soll crosion near hydro facilities by protecting watersheds and to reduce the impact of global warming in CARES program countries. Although the latter objec ive of this activity is commendable, the impact on global deforestation and carbon sequestering from the plantation of trees would be minimal. Moreover, the record of government sponsored reforestation projects has been shown to be cositly to establish and to maintain. Clearly, member contributions should be used to their greatest advantage, the CARES program should consider if reforestation projects would be the hest use of these scarce resources. For example, watershed protection activities, dissemination of secdlings to farmer groups, funding of species screening and selection are among activities that might be a more cost-effective use of member contributions.

As noted elsewhere, the current CARES stalf are already overly committed to activities that are more pertinent to rural electrilication. The use of local CARES stafl to take on new initiatives, especially ones that are outside of their area of expertise would have the effect of diluting already critical management resouress. This type activity should be coordinated from the Washington office.

Any activities in reforestation should be done in a complimentary role to wood pole production or be related to other aspects of the project. For example, CARES stalf' may want to consider conducting studies to evaluate the potential impacts of deforestation on the siltation of reservoirs and the loss of capacity and use the results of study to eommenicate the eflects of deforestation on Central Americin power resourecs.

\subsection{COUNTRY ACTIVITIES}

\subsubsection{Belize}

Activities for Belize were originally focused on technical studies, productive uses and demand assessment. Basically, NRECA attempled to implement the standardized approach to rural electrification involving the application of the demand assessment model and productive use promotion. A produclive uses seminar was conducted in June 1988 with some follow-up activity.

The Belize Electricity Board (BEB) has expressed litte interest in rural electrification as it was oceurring in Belize (response 10 political pressure with isolated diesel systems initially financed by local government funds and turned over to BEB lor management). Following the new government in 1989, NRECA was given more encouragement and subsequently undertook an evaluation of electrifying the Stann Creck district. The results of the NRECA cvaluation repori indicate that this project would be financially unattractive.

The Stann Creck proposal was followed by a more comprehensive proposal requested by the Ministry of Mines and the BEB to create BREMA -- a cooperative solution for meeting the needs of rural areas. Eight rural villages were solected for consideration. These villages have either functioning or nonfunctioning isoluled diescl systems. The proposial is currently under review by the BEB and the Ministry of Encrgy. One potential problem of the BREMA proposal to the BEB is the loss of the financially attractive service area near the Mexican intertice. BEB believes that NRECA 
should be eontined to areas that are elearly isclated. However, there is strony support from the Ministry, which belicves that BREMA would give BEB breathing space $t o$ impt sve its systems.

The technical challenges to rural electrilication in Bellize are more substantial due to the diflerent philosophical approach of a three phase ungrounded dolta distribution system. These types of systems always result in a mathematically elegant design but are not sulted to rural electrification. Provision for a single phase extension of the current distribution system is difficult. Realistic project goals in Belize are best understood if the lechnical activity is divided into two separate categories. The lirst is these standards that relate to the system configuration (c.g., voltages, 3 phase configuration etc.). The second category of technical activities is those standards that relate to eonstruction of the distribution lines (c.g., pole spacing, conductor selection, etc.).

These standards are not mutually dependent and thus should be considered in different lights. However, in both cases the (BEB) or the new BREMA will need to be convineed of the benefits before widespread adoption. The challenge in Belize is not so much the writing of new standards, as in Guatemala, but rather 10 use typical REC standards in several demonstration projects to promote confidence in changing both typess of staudards.

Because of the influence of the NRECA Stafl, the Belize Electrification Board has just crealed a new Rural Electrilication Commiltee. Cooperation with the BEB has been progressing at a promising pace. NRECA assistance with the $34.5 \mathrm{kVA}$ sub-transmission tie-line from Mexico is an excellent opportunity to show how diflerent construction standards can save a substantial amount of money. The majority of the savings will be due, in large part, to increasing pole spacing.

Isolated power. Isolated power supply requires NRECA to more closely address the basic question of rural planning versus rural electrification. Rural energy planning should be placed in a broader policy conlext in which rural electrificasion (i.c., grid extension) is just one option among other energy alternatives, such as renewable em rgy technologies (mini-hydro, PV, wind, biomass). In many cases, a mix of energy alternatives (c.g., PV for home lighting and small appliances, and diesel gensets for productive use activities) may be a more cost-effective alternative to an integrated isolated system or grid extension especially for villages where connections are dispersed.

A short field trip was laken to Crooked Tree, a proposed arca under the BREMA. The trip demonstrated the problems encountered in the construction and maintenance of isolated rural systems. Connections were widely spaced, power use rales low, and tariffs relatively high. Examining the proposed rehabilitation costs and costs for a upgraded system indicate that a system of PV pancls for lighting and sinall appliances and small single-user gensets would be considerably less costly than a multi-user diesel system. Moreover, there would be much less maintenance required and only minimal fuel and operating costs.

The BREMA proposal is a major opportunity to impact. rural electrification in Belize and should be aggressively pursued. However, further consideration should be given to dispersed and renewable energy generation lore servicing more remote village londs in the inoplementation of this proposal.

One of the potential stumbling blocks to a decentralized power program and for productives uses investment is the lack of eredit for purchasess or the mechanisms to effectively distribute and manage credit. There are several polential groups which were described to the evaluation team 
during Interviows that might be approprlate for the provision of credit, ceg, the Canc Farmers Association (perhaps 6(K) larmers with about 20 acres cane each) and Citrus Growers Associate; arad the Belize Enterprize for Sustainable Development-located in Belmopan. The National Development Foundation of Belize (INDFB) could also play a role. The NDFB provides loans of up to $B \$ 25,(K)$ ) for small business. (Loans details provided in their annual report indicale a delault rate about $5 \%$, with about $5,(0) 0$ loans made in the last six yeurs). The program appears innovation and effective. USAID is about to provide another $\$ 2.5$ million in support. Additional support is coming to the NDFB from the EEC, the EDF, and Government of Belize. Training and business advice are provided as part of the loan package, and NDFB works closely wilh other NGOs to provide credit lines.

\subsubsection{Costa Rica}

The CARES program has been substantially involved in a number ol new iniliatives in Costa Rica, including private sector and eooperative power generation and alternative means of linancing. CARES stalf have worked closely with the USAID Mission to help implement privatization policy objectives, for example, via a privaltizalion seminar recently held in Costa Rica.

The CARES project staff and the local USAID Mission have played an essential role in the development of CONELECTRICAS. 'This is a consorlium of the rural electric cooperatives in the form of a geracralting and transmission conperative. CONELECTRICAS has chosen a $16 \mathrm{MW}$ hydroclectric proyect as its lirst gencration station. "This has been a diflicult task to date beciune of the arbitrary procedures used by ICE for site selection. Several feasibility studies with positive recommendations were conducted before the San Lorenes site was linally agreed upon. The new government has been assisted by the CARES Staff' and has committed to the general goals of decentralization and privatization. The suecess of this activity will be a hallmark for the entire CARES Project. CARES stafl will need to continue the close support in this area and provide technical assistance in the area of determining the marginal cost of electricity production.

CONELECTRICAS has several other initiatives to assist in Jowering the costs of new construction and maintenance. These are very worthwhile and can potentially have a big impact, especially in the areals of meter calibration, transformer reconstruction and wood pole quality assurance. At least one additional engineer is needed to continue the momentum and pade of activily. It is strongly suggessted that someone be hired to work full time in Costa Rica.

In addition, CARES has worked with the USAID Mission to develop an innovative debt swap, proposal to the Costa Rican Government, which would facilitate linancing of a new small-scalc cooperatlec or private sector power. CARES long-standing relationship with rural cooperatives in Costa Rica has been elfective in supporting Mission and ROCAP policy objectives.

\subsubsection{El Salvador}

The CARES program was instrumental in the justification and design of the major rural electrification project in Eil Salvador. This $\$ 10$ million program has been coordinated with the CARES regional program, and components and the skill mix of stall' appropriately and effectively blended. CARES pliyed a major role in the creation and stalling of the Consumer Serviecs Department with Comisión Ejecutiva Hodrocléctrica del RIo Lempa (DISCEL) in El Salvador, along wilh the CARES resident advisor). 
Substantial emphasis in El Salvador has gone into the productive uses promotion including the placing of' a productive uses demonstration trailer. T'wo productive uses studies have boen completed. These include a usige study to target productivi uses to residential users; and a productlve use study to assess the viability of electric power in bustness applicalions, determine the impacts of outages on businesses, devolop business energy usage profiles, and examine the availability of eredit. This latter study made several recommendations for credit structures and proposed a seminar to bring all players togother. A report was issued based on the productive uses seminar. In the report there were recommendations relating to follow-up activities, the development of a projects data bank, credil alternalives, and demonstration equipment.

Credit for productive uses is a botlleneck lo widespread dissemination. Currently the credit prosrams for productive uses are being developed in two institutions. Comisión Ejecutiva Hidrocléctrica del Rfo Lempa (CEL) will provide credlt at a reasonable rale for users necding to re-wire to aceommodate an anticipated productive use. This program involves the delivery of materials and CEL later that the user is required to pay back. This approach appears to be attractive because of the large discounts for quantity purchanes. Federal Credito will also be making loans available at 22.5 percent.

Finally, the productive use pamphlets now being published by CEL are a good start in the promotion of power. This type of promotion is needed and demonstrates to some degree institutional reform. The management training trip to Chile had a signilicant impact on CEL management and the institutional cullook lowards cooperatives and efliciency, It seems as though CEL may now be more positively disposed to the idea of eopoperatives.

\subsubsection{Guaternalda}

Major CARES activities in Guatemala include promotion of productive uses, application of the demand assessment model, locial manulacturing, rural electrilication standards, and surplus equipment.

Productive Use in Guatemala. Productive use interventions form one of the eentral elements of the project, In order for PU intervention to be suecessful, there are various associated conditions which must be present, or factors to be adedressed. These factors should be explicitly incorporated in the productive use intervention strategy. For example, a) productive uses promoted must be feasible given the overall policy conditions, prices, taxes, regulations and marketing systems for the products produced, b) other necessary infrastructure needed must be available or obtainable; these include roads, maw matcrials, skills, and repair and maintenanec, spares, elc, e) eredit must be supplied where needed, and eredit and technical assistance packages must address the real constraints that might limit investment and eflective implementation.

Productive use activities of the CARES project in Guatemala are closely linked technically with the demand assesssment (DAM model) activitles, and are an integral part of INDE's PER-III productive use:i program. A productive uses seminar was held in Guatemala early in the project altended by 60 persons from INDE and over 20 from other public and private groups. Subsecquently, a commitlec, Comite de Acrion para los Usos Productivos de la Electricidad (CAUPE), was formed with the role of defining the pelicy environment for productive uses as innut to the DAM model, and (o) stimulale interagency attion on productive use program design. Some 14 meetings have been held since CAUPE began, with primarily INDE: and NRECA stall attending alter the initial mecting. It 
is hoped that the CAUPE will return to its original composition and lunction onec the PER-III project is begun. While the commiltec appears to be a well-concelved idea, its effectiveness is yet to be celearly demonstruted.

Several major productive use tasks were undertaken in anticipation of the start of PER-III. These included an inventory of equipment, detailed surveys of end uses with and without electricity (for input to the DAM model as woll), and a study and evaluation of demand and eonsumption of electricily (load study). In addition, due to the delay in PER-III start-up, CARES prepared a proposal, which was circulated secking funds for credit support for productive uses. Both the Italian Cooperation Agency and the Fundacion Desarrollo para La Mujeres have agreed to provide support. In the absence of the INDE Technical Advisor Position under PER-III, CARES has moved aggressively $t($ get the INDE program started in this area. This effort appears to be well-conceived as the CARES project has only two years remaining and has substantial productive use targets' to mect in that period. This action furthermore, has placed Important development needs ahead of a legitimate burcaucratic justifleation to simply wait and resume work in this area when PER-III proceeds.

The terms of reference for the INDE Productive Use Specialist position are contained in the PER-III project paper. The Specialist is to provide Fundacion para el Desarrollo Integral de Proyectos and Accion Internacional Technica (FUNDAP/AITEC) with direct technical support, as well as to supervise and train INDE personnel in productive uses. However, it is unclear how this position will relate in practice to FUNDAP/AITEC activities, which will be executed by contractors performing community training and technical assistance, respectively. The project paper seems to foresee a strong role in this regard, but indications are that this will be complicaled to achieve. Likewise, how will the Specialist interact with or be affiliated with CARES or NRECA if at all? CARES stafl' have suggested the closest possible relationship to the CARES program, including hiring the advisor through USAID as originally intended and locating him/her in CARES oflices. While this might be the optimum from an elficiency standpoint for technical interaction and logistical support, this arrangement would not tend to have the same strong institutional development benefits as fulltime location in INDE. Based on the information at hand, partial aceeptance of this suggestion is recommended: the USAID Productive Uses Specialist should begin work directly with NRECA/CARES lor orientation and training, with transfer to a full-time basis at INDE over a 3-4 month period. Strong technical and institulional linkage to NRECA is important for the Advisor to suceced and would be obtained under this option. At the same time INDE and PER-Jll would be visibly and directly served.

A critical component of the NRECA agenda is the rural development and productive uses augmentation. Some of the productive uses literature reviewed in the evaluation, however, presents an oversimplified view of the relationship of electricity to income enhancement. This perspective contributes to an inadequate consideration of the relative economic benelits of different productive uses in, for example, current proposed indicators of project impacts. It is important to place the ultimate goal of income and social cnhancement ahead of simply maximizing electricity use. Practically speaking, staff are aware of these issues, and the demand model properly evaluates different end use benefits. However, it is essential that proper economic principals be applied throughout the project, including being reinforeed in formal literature and productive uso workshop training case studics. 
Another implication of the income and social development cuhancement objectives of the project is the need to supplement the CARES program with small-enterprise development expertise at the field level. Excellent support is being provided lor this area, among others by Ivan Azurdia, but this is only on a part-time appointment and primarily to serve the program in Cuatemala. FUNDAP'AYTEC should be able to fullill this role at the PER-lll credit program level. The overall CARES regional support lunction and direct INDE support activity of NRECA would be well-served by better definition of productive use promotion activities and permanenl local-hire specialist. The addition ol a project economist (or other appropriate social seientist) within currently budgeted activities (by shifting from short-term technical assistance) would also be helpful in light of the importanee of the enterprise development issuc. However, specialized lield-oriented expertise is still going to be required, particularly for the implementation work required for productive uses.

NRECA has initiated training activities at INDE for social workers and middle management on productive use related topies. This training is oriented toward performing demand assessment' surveys and analysis of needs. Additional training is planned at a higher level and is needed to prepare those at the middle-management level (INDE counter part productive uses specialist) for future activities. In general, the future field level promotional and technical advisory role of the INDE Productive Uses Specialist and other productive uses stafl' vis-a-vis FUNDAP/AITEC, as noted above, appear unclear and fraught with potential problems. This area deserves both more consideration and mutual agreement of roles and responsibilities at the working level between USAID, INDE and FUNDAP/AITEC, before FUNDAP/AITEC begins implementation.

The CARES project also plans to develop promotional materials and activilies designed to complement the PER-III productive use activitics of INDE. CARES will also continue to offer technical assistance both directly to INDE and to the separate productive uses credit activities (FUNDAP/AITEC or other NGOs with the willingness to participate).

The budget for all of the above CARES activities in support of PER-III areas as programmed should be considered part of the core budget. Due to the delay in PER-III start-up, CARES effectively substitules in-effect for the productive uses adviser a situation that should receive reconsideration.

The most potentially perplexing and important issue for CARES and PER-III in the productive uses arca will be the effective implementation of the credit component. This task would be difficult enough within a sell-contained project. However, this is not the case; rather a complex set of interrelationships between INDE, FUNDAP/AITEC and NRECA is required, not to mention the division of management responsibility between the Mission Private Sector Oflice and Energy Office (Enginecring). The division of responsibility between these two offices should be carefully reconsidered. Moreover, USAID should exereise vigorous management oversight, and should insist on coordination between both NRECA and FUNDAP/AITEC, as well as between INDE and FUNDAP/AITEC.

In principal, the lack of a strong INDE role in the PER-III productive uses and credit program under FUNDAP/AITEC appears unwise. Furthermore, given the unique and extensive experience of NRECA, they must play a major supportive role lor the FUNDAP/AITEC to be elfective. While the guestion of how to achieve this is unclear, the necessity is obvious. NRECA is presently establishing a smaller, more closely integrated productive uses program with INDE. This 
can both serve as a model and a stimulus to FUNDAP/AITEC. However, it is important that this be a complement to, and not a replacement for, the FUNDAP/AITEC work.

The productive uses program has the potential to produce a significant beneficial impact on INDE's or other Central American national utility finances, as well as to enthance rural income and well-being. The focus of the PER-III credit activity will be on very small micro-enterprises, which comprise only a portion of the small enterprise market for technical assistance. Other groups such as the Comision Nacional para el Fomento de la Microempresa y la Pequena Empresa (among others), target larger but still small enterprises, for example, less than 8 employees. CARES should seriously consider augmenting its productive uses initiatives at INDE by working with such credit and assistance groups serving larger micro-enterprises. This augmentation would provide an example of a more extensive range of enterprises, provide complementary but different experience to that of the FUNDAP/AITEC activity, and possibly demonstrate potential for more macro-level impacts for INDE.

Demand Assessment. Demand assessment activities in Guatemala were initiated in FY88 and completed in early FY89. Refinements to the model are ongoing. Two of the more straightforward tasks to applying the model in rural Guatemala have been generation and distribution costing, including the measurement of rural loads. The intent of these studies was to estimate the marginal costs (energy and capital) of supplying power. Overall, these activities were done well by NRECA staff and the local consultant using an appropriate methodology and set of assumptions.

In addition to estimating the marginal costs of supplying rural power, two field surveys and studies were undertaken -- site selection and estimation of productive use benefits. The purpose of the site selection study was to identify characteristics that would help distinguish low and high productive use communities. The field survey for this study was conducted using recently electrified PER II communities. The field survey for this activity was slow in getting started. The result was that the same communities could not be used for the productive uses survey.

The estimation of residential and productive use benefits study is the critical component to the application of the DAM to rural Guatemala. This study was undertaken in early 1989 in which nonelectrified and electrified communities were evaluated for productive uses. Twenty-seven productive use activities were evaluated for cost savings, production increases, and quality improvements. Given the short duration of this evaluation it is impossible to say with precision the validity of these estimations. Time did not permit an in-depth analysis of the empirical results of the study. It can be said, howeves, that the methodology used for the estimation appears to be sound. The validity of the estimates of benefits per $\mathrm{kWh}$ consumed remains an empirical question. As an aside, productive activities that have negative benefits should be excluded from the estimation of benefits (c.g., coffee processing and blouse embroidery).

These studies were completed with a combination of local NRECA staff and local consultants. In general, the performance of NRECA staff has been commendable. The DAM application is being enthusiastically managed by local NRECA staff. The model is currently at the fine-tuning stage. The potential to produce exceptionai results in final PER-III site selection is high.

Onc potential weakness of demand assessment application may be in getting utilities to use the model for initial screening activities and for assessment of productive uses. In many cases, utilities are already using a model or methodology for initial screening and site selection and they may be 
unwilling to abandon ingrained practices especially in light of extra lield staff time required (higher level of data collection and interpretation), the need for specialized training, and the need for computers.

The application of the DAM should be pursued in the PER-III site selection process, especially as it relates to initial screening. The approach of using a structured decision framework for data collection from initial to final site selection is good.

As noted earlier, a major criticism of the model is the somewhat high data requirements. The value of sociocconomic surveys to identify high and low productive use communities is dubious especially in light of the insistence of INDE to use their model for this activity. Attempts should be made to synthesize the key resuits of this study for other country applications.

A critical element to the DAM applications is the validity of productive benefits. Attempts should be made to explicitly validate these model parameters. Moreover, as noted earlier, structured sensitivity analyses should be undertaken to gauge the robustness of estimated parameters.

\subsubsection{Honduras}

The USAID Mission in Honduras is supportive of rural electrification efforts; as well as efforts to support improved performance of ENEE. However, the Mission finances no direct programs in the power sector. The Mission's role has been one of facilitator, not of a substantive participant in the determination of work to be done. NRECA has been responsive to requests for support of policy objectives of the Mission, e.g. the privatization seminar held in Costa Rica and the planned trip to Chile.

The Aguan Valley Socio-Economic Study component of CARES represents an important opportunity for review of a major USAID funded electrification project. It is important to USAID to know what were the results and what lessons can be learned to improve other similar efforts.

Empresa Nacional Energia Electrica supports productive uses concepts and urged CARES to provide technical information assistance as soon as possible. It would be highly desirable for CARES to revise its plans to include Honduras productive use activities as soon as possible. Examples, like the Aguan Valley project, which ended in 1985 with very low reported rates of power utilization and very few productive uses, make Honduras a stimulating exercise.

Demand Assessment Model. Currently, decisions on connections policy for rural electrification are very political. The CARES demand assessment model application to Honduras could be very important to provide rationality to the ENEE system at this time, particularly since several new projects funded by the EEC or Venczuelan Investment Fund are planned. ENEE is one of the few utilities to apparently not have its own model for evaluation of connection costs and benefits, making the DAM model application here potentially more important and practical.

Standards for rural electrification. Only written information on the standards for Guatemala has been provided to ENEE. There has been training to some ENEE staff, but no direct technical assistance in this area. ENEE has now formed a committee which is working on the development of new rural standads. This would also appear to be a golden opportunity for the project to participate with a receptive partner in a timely application of previous standards experience. 
Organization/Institutional Development. ENEE does not now have the institutional structure (appropriate organizational unit) to absorb or manage a large rural electrification technical assistance input. In the past, there have been project specific development groups, but these only exist during the execution of a specific project. However, it was felt that adequate technical staff can be found to cooperate with a substantial CARES initiative. However, practical planning and budget considerations dictate 6-9 months lead-time where new vehicles, materials, etc. must be procured. These latter issues point up the need to have a clear NRECA Honduras program to allow the ENEE to plan.

Irrigation Rate Study. This tariff study was undertaken to ascertain the feasibility of utilizing off-peak power for irrigation and other agricultural uses. Greater off-peak energy sales could provide increased revenues to ENEE for system expansion and to better cover operating expenses.

A review of the preliminary draft of the study indicates that in general there was too much focus on demand side activities at the expense of providing a more logical methodology for determining tariffs for ENEE. For example, if it is assumed that existing conveyance systems would be used for electric pumpsets then the detail on alternative irrigation methods (sprinklers, drip, surface), soil types, and crops appears to have been unnecessary. In addition, many of the institutional constraints to greater use of electrical pumping were not given sufficient attention. These include distance to grid tie-points, costs for line extension, the availability of electric pumpsets in various sizes, reliability of the local grid, the importance of pump portability, financing mechanisms for line extension, and approaches for administering off-peak power (ripple controls and time of use metering).

ENEE needs to have a methodology that could be used in analyzing tariffs. A revised study report should emphasize the tariff methodology as well as the constraints and institutional aspects of promoting off-peak energy use.

Feasibility Study for Cleation of Cooperatives. NRECA has proposed at ENEE's request, with Mission concurrence, to conduct an in-depth study of the financial and economic feasibility of creation of electric cooperatives for decentralized management of rural electric service. The study would be accomplished in two steps; first, faet finding to determine the climate and overall feasibility, and if warranted, a field survey to deline the basis for a feasibility study; and second, a full feasibility study for the creation of electric cooperatives. A consumer education component is also suggested. Documentation for a funding proposal would be assembled, but neither a funding proposal nor funding plan is explicitly required.

In July 1989, Jim Lay met with John Sanbrailo, the Mission Director. Mr. Sabrailo expressed concern that the Germans and Venezuclan Investment Fund were funding electrification in the country, and that these projects were being "overbuilt" and were not soundly based economically. Also noted were ENEE's expectations that Italy. France and the NORDEL company, an association of Nordic Electric Companies, and NORAD would be financing rural electrification. Clearly the payoff from donor coordination and CARES activity in Honduras could be substantial, with results tailored to eomplementing and rationatizing other donor capital projects. Given the likelihood that the USAID Mission will not be financing additional rural electrification, it is strongly recommended that CARES: (1) offer to coordinate general rural electrification plans in Honduras and the role of the various donors, (2) seck to inlluence and participate in the direction of those activities (for example, through technical assistance to ENEE, training of ENEE, demonstration and promotion of 
the DAM model, etc.), (3) tailor the Honduras work program to directly complement (rationalize) planned rural electrification investment, and (4) if possible, attempt to directly incorporate support for CARES initiated efforts, such as standards implementation and productive uses, with IBD activities. 


\section{FINDINGS AND RECOMMENDATIONS}

Results are very evident in the areas of engineering design and productive uses promotion. The planning and enginecring sections of INDE and CEL rapidly adopted the new mechanical strength-based standards as reasonable design solutions. This result is not a trivial matter sinee it involved a whole new way of thinking. Similarly, productive uses has received much greater attention by all of the various divisions of the utilities in El Salvador, Guatemala, and Costa Rica. This attention to productive uses of electricity was not the case provious to the CARES Project.

Other results and evidence of institutional reform is the rapid embrace of decentralization and privatization. Jim Lay (CARES Program manager) has played a vital role in this change through management training at INCAE. The formation of Electric Cooperatives in Honduras is one example. Another example of decentralization is an invitation to consiver alternatives to conventional grid extension and to prepare and negotiate a new rural electrification authority in Belize.

Other specific accomplishments include the development of the demand assessment model and donor interest in applying the model to other regions; the development of strong cooperative relationships with all counterpart utilities; the value placed on technical training programs by utilities; and the suecess in leveraging local currency to greatly expand the El Salvador program.

The success of the project to date is especially noteworthy considering the state of rural electrification prior to the project and the limited number of CARES professional staff to carry out the wide range of planned regional and country specific activities. Despite the suceess of the project, there are some areas where changes can be made in operating procedures and in the direction of ecrtain programmatic activities that can lead to an even more effective project. The remainder of this chapter summarizes these recommended changes.

\subsection{PROJECT MANAGEMENT ACTIVITIES}

Financial reporting. Clarification of the content, routing and schedule for financial reporting is needed for ROCAP to do more responsible project monitoring. NRECA headquarters should take responsibility for clarifying the official routing of information, determining ROCAP's minimum needs and to the best of its ability attempt to facilitate meeting these requirements.

ROCAP monitoring. In general, the ROCAP project manager should maintain as much operating familiarity as possible with the project, including monthly briefings. Occasional travel to CARES country project sites with staff is also essential for the project manager to fully exereise his monitoring and approval responsibilities.

Project monitoring. It is strongly suggested that project monitoring be systematized with the Annual and Semi-Annual report carefully reviewed by ORNL and commented upon, and preferably thereafter a joint review meeting held with the ROCAP project manager, ORNL and NRECA every

six months. Future project evaluation should continue to utilize a local counter-part consultant to facilitate the review and to provide insight into local conditions, policies and priorities.

Impact Indicators. It ti recommended that specialist assistance (not project staff) be sought to finalize impact indicators. The project is in its third year, entirely too late for these issues to 
remain outstanding. A plan for the compilation of noeded data and stalling requirements to meet this need should be an additional part of this task.

\subsection{REGIONAL ACTIVITIES}

Training. Training needs are not clearly defined nor are country specific plans. U.S. based training and comparative management training may noed rescoping, operations training is far behind schedule, more attention is needed in the commercial area, and productive uses training is not receiving adequate emphasis. Funds allocated to this activity are inadequate. If additional funds are not fortheoming, a training plan and recommended list of euts in other areas should be prepared.

There should also be an organized and methodological documentation of results from training. This documentation could take the form of a brief attendec report on the results of training both in terms of direct application of lessons learned, as well as a follow-up report on implenented improvements.

Enginecring Standards and Technical Activitics. The sub-station metcring program in El Salvador is in place and working well. Although it is a local USAID initiative, this program presents an excellent opportunity for operations training in the other countries. This activity should be pursued in much the same way as the complater-aided distribution design course.

During the standards technical review it was suggested that the transformer losses activity be de-emphasized sine the effort would not be worth the gains. This conclusion is still valid. Although this activity has'some merit, given the constraints on staff resourees it should be given a low priority during the remainder of the project. Instead, assistance should be directed towards management training for better control of non-technical losses.

The surplus equipment program needs to be managed and supported by NRECA in Washington to liree the CARES stalf 'rom many of the coordination tasks. The CARES staff should be responsible only for disseminating the inventory and the technical support necessary for selection.

The import of the raw materials is so difficult and expensive that little basis can be found for pursuing this activity very vigorously. The potential gairs are insufficient to warrant much expenditure of limiled staff time. It is recommended that this activity be de-emphasized.

The efforts in wood pole technology should be continued but with a well-defined perspective as it relates to promoting rural electrification. CARES can have a significaut impact in two areas: training utility personnel in wood treatment quality assessment and in establishing a regional standard on the proper production, grading and treatment of wood poles.

Demand Assexsment. The project should pursue the use of the DAM in the PER-III site selection process, especially as it relates to initial screening. The approach of using a structured decision framework for data collection from initial to final site selection is good. Training of local utility counterparts is cncouraged as well as carly integration of counterpart staff in country specific applications. 
The: value of socioceconomic surveys to identify high and low productive usc communitios is dubious especially in light ol' the insistence of INDE an use their mockel lor this activity. Attompts should be made to synthesiles the key results of this study for other country applications.

The DAM model requires a eonsiderable amount of data as well as the need for truined stalt to ensure that the model is consistently applied. Allempts should be made to understand how preductles use activities correlate among countries to see li data collection elforts might be reduced and made less burdensome. A critical element to the DAM application is the validity of productive use benefits. Altempls should be made to explicitly validate these model parameters. Moreover, additional struetured sensitivity analyses should be undertaken to gauge the robustness of estimated parameters and $t o$ isclate key system parameters in hopes of focusing data collection efferts.

The extensive applicability of the model suggests that it should be more widely disseminated. NRECA stal'? should corisider publicution in peer-reviewed development or energy journals for more prolessional recognition.

Reforestation Initiative. The CARES stall' should avoid taking on responsibilitics in reforestation that would have the eflece of cilluting already critical management resources, Any activities in reforestation should be done in a complimentary role to wored pole production or be related to other aspects of the project. For cxample, CARES staff may want to consider conducting studies to evaluale the potential impacts of deforestation on the siltation of reservoirs and the loss of capacily.

\subsection{COUNTR'Y ACTIVITIES}

The CARES Projed will only have an impact if it ean devote full-time labor resources in specific countries. It is highly recommended that full-lime staff, preferably local nationals, be hired to work in place of short-lerm consultancies. For cxample, in Costa Rica a full-time staff person could help ensure momenlum is not lost and serve as a facilitator for the various other CARES initialtives.

Belize. The BREMA proposal is a major opportunity to affect rural clectrification in Belize, and should be aggressively pursued. Further consideration should be given to dispersed and rencwable energy generation for servicing more remote village loads in the implementalion of the BREMA proposial.

E Salvador. There are no specilie recemmendations suggested for El Salvador activities.

Costa Rica. It is recommended that a full-lime stall' person be hired to oversec Costa Rican activilics.

Guatemala. CARES productive uses training, extension and credit initiatives appear 10 be well-conceived. The USAID Productive Uses Specialist should begin work directly with NRECA/CARES for orientation/training, with trassler to a full-time basis al INDE, over a 3-4 month period. The overall CARES regional support function and direct INDE support activity of NRECA regures a permanent local-hire specialist. 
The future role of the INDE Productive Uses Specialist and other INDE productive uses stuft vis-an-vis FUNDAP/AITEC productive uses program, deserves further deflndion. USAID's split management responsibility for the PER-1II project ma contribute 10 this problem. It is recommended that there be (1) reconsideration of spllt of USAID management responsibility; or (2) vigorous USAID initial management oversight and coordination to ensure close working relutionships and coordination at two levels, first, between NRECA and FUNDAP/AITEC, and second, botween INDE und FUNDAP/AITEC.

CARES should scriously consider augmenting its productive uses initiatives at INDE by working with credit and asslstance groups serving larger microenterprises. This activity would provide an example of a complementary but different experience to that of the FUNDAP/AITEC activity and demonstrate potential for more macro-level impacts.

Honduras. NRECA should start as soon as possible to implement the comprehensive demand assessment, productive uses and standards activitios in Honduras. These activities should be consistent with the capacity of ENEE to absorb assistance. A full-time technical specialist placed in Honduras would be the appropriate means to aceclerate the rate of implementation of this prograrn.

The NRECA draft irrigation tarill report needs to be revised and/or repackaged to emphasize tariffs. A revised study report should emphasize the tarifl mothodology as well as the constraints and institutional aspects of promoting ofl'peak energy use.

It is recommended that CARES: (1) offer to coordinate general rural electrification plans in Honduras and the role of the various donors, (2) seck to influence and participate in the direction of those activities (for example, through lecthnical and training assistance to ENEE, and demonstration of the DAM model, etc.), (3) tailor the Honduras work program to directly complement (rationalize) planned rural electrification investment, and (4) incorporate support for CARES initiated eflorts, such as standards implementation and promotion of productive uses, with IDB activitics. 


\section{APPENDIX 1: LIS'I' OI' PLERSOINS IN'TERVIEWIED AND SITTES VISITTED}

\section{I3cline}

Mossina Jordan, Mission Chicli, USAID

Art Villantever, Project Development Olficer, USAlD

Carless Diaz, Mindster, Ministry ol' Encrey, 'Transportalion, und Communication

Louis Lue, Chiof Exceutive Olliecr, Belize Electricity Bond (BEB)

Fernundo Coye, Director of Operatlons and Englnoering, Belize Electricity Bonrd (BEB)

Joseph Sukhandan, Projed Manager for World Bank Project 1, Belize Electricily Board, (BEB)

Arturo Gallegr, Privule Consultant

Stephen Gillete, Program Ofticer', National Development Foundation of Belize (NDFB)

Lou Nicolatit, Belize Center for Environment

\section{Costa Rica}

Heriberto Rodrigue\%, Development Enginecr, USAID

Hernan Bravo, Minister, Ministry of Nalural Resources, Encrgy and Mines

Sigifredo Solis, Manager, COOPEAl.FARO-RUIZ, and President, CONELECTRICAS

Carlos Rodriguez, Manager, COOPELESCA, and General Manager, CONELECTRICAS

Misacl Monge, Manager, COOPESANTOS

Fernando Moya, Mannger, COOPEGUANACASTE

Javier Matamoros, Private Power Supplier

Leonel Fonscear. Consultor de Empresia

El Salvador

Raúl Gonzále:, Olicial de Proyectos, MIB, USAID

Myk Mannon, NRECA 


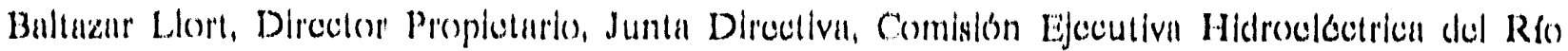
L.cmpu (CLL)

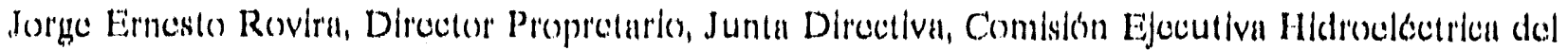
RIO L.umpa (CEL)

Gregorio Avila, Gerente, División de Distribución de Encrgán Eléctrica, Comisión Ejecutiva Hodrocléctricia del Rés Lempa (DISCEL)

Leonal Bolaños, Jofe, Socolón Comercial, Companfa de Alumbrado Elétrico de San Sulvador (CAESS)

\section{Guatomala}

Ron Nicholson, Deputy Director, ROCAP

Ann MacDonald, ROCAP

Mario Funds, Regional Energy Olflecr, ROCAP

James Lay, Program Manager, CARES

Ron Orozeo, Productive Uses Specialist, CARES

Ross Turncr, Enginocring and Training Activitios, CARES

Ivan Azurdia, Gualemalan Activitics, CARES

Ruberto Figueron, Development Specialist, USAID

Ing. Rodolfo Santizo, Gerente de Operaciones, Empresa Eléctrica de Guatemula, S. A. (EEGSA)

Eduardo Barricntos, Director of Planning, Empresa Eléctrica de Guatemala, S. A. (EEGSA)

Ing. Luis Ortiz, Asesor, Departamento de Planifieación Energetica, Ministerio de Energfa y Minas (MEM)

Ing. Ciermán Obiols, Jefe, Unidad de Planilicación del Sistema Eléctrico, Instituto Nacional de Electrilicación (INDE)

Ing. Ricardo Cáceres, Gerente, Proyectos Nuevos, Ingenio Pantalcón 


\section{Honduras}

Hugo Elvir, Enginecring Orliken, USAID

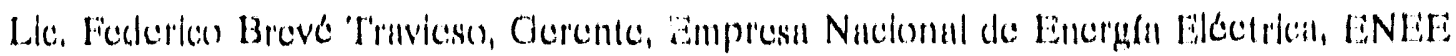

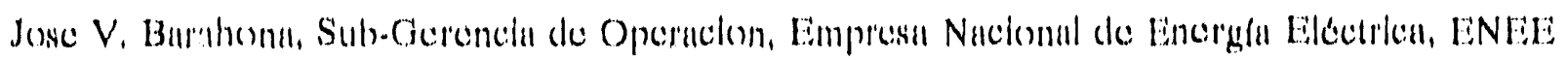

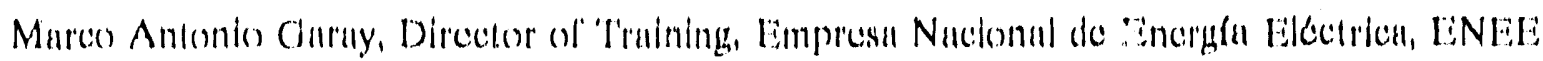

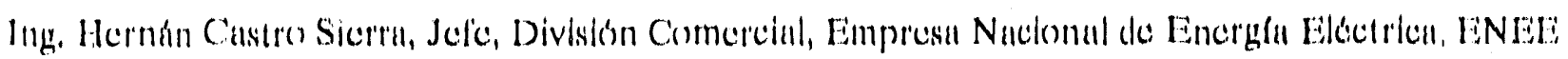

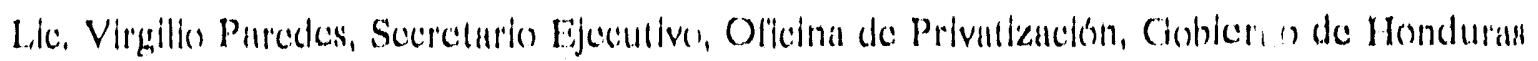

Ënesise Bondy, Irrigution Consultant

R. Martinc\%, Irrigalion Consullant 


\section{APPIENDIX 2: LIST' OF DOCUMIN'IS RLVILWIUD}

Bl-woekly regunts ol' dim Lay, Ross 'Turner, Ron Orogen, Ivan Azurdia, Myk Munom, and Aldon Kilson

Trip reports al' Jin Lay, Ross T"urnere, and Ron Orozeco

CARES (984) and lo9) Annunl Workpluns

CARES 198') Annunl Rupurt

El Sulvador Monthly Summary Reports

CARES Monihly Summury Reports

All CONELRE'TRICAS Projoct and Consullant Roports

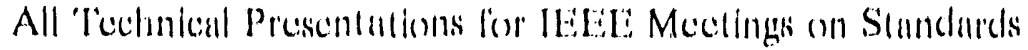

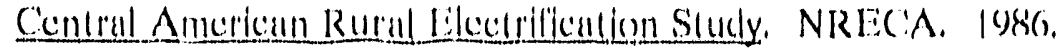

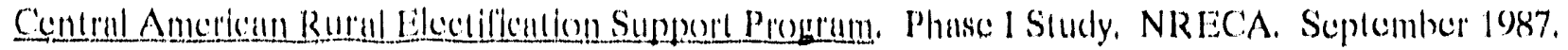

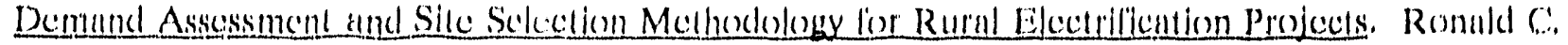
Orezen, ol al. June 108\%)

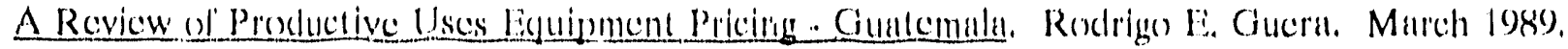

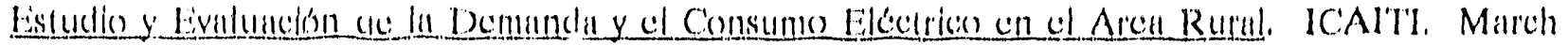
1989.

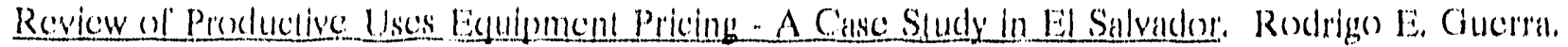
May 1989. (Reproduction by NRLCA/Eil Sinvador.)

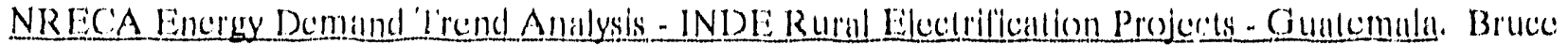
Newmin. May 1989.

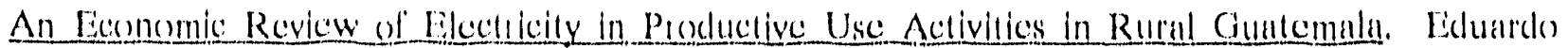
Villagrán, June 19899.

Application ol Demand Assessment Model: Shont-Turm Residenlial Analysis and Productive Use Activity Scelection in Guatcmale. Stephen O. Stewart. (Filnal Repert.) June 1989.

Nuevos Criterios en Electrilicencion Rurul en Gumlemula. Javier A De León und Rosss M. Turner. Junc 198\%. 


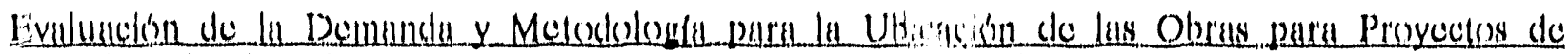

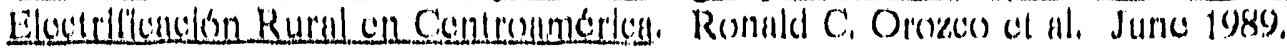

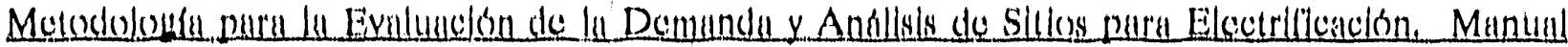

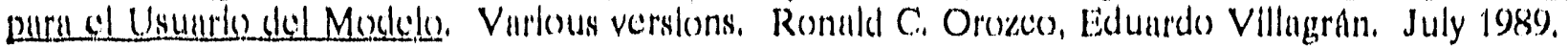

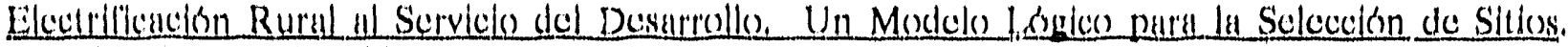
Pamphate. Lidunrdo Villagrán. Scptember 1989.

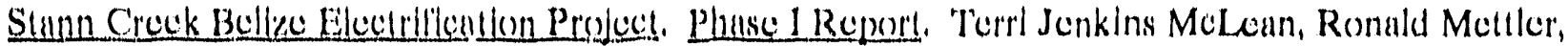
Ress M. Turner, Romald C. Orozoo, Outober 1989.

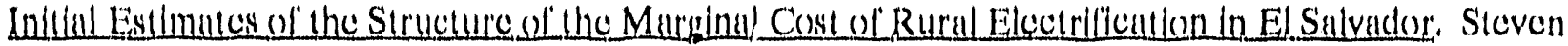
C. Fischer. August 1989.

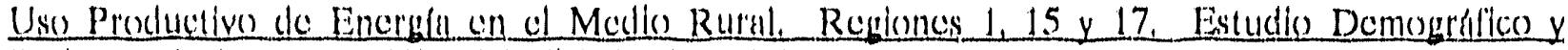
Sodocounomico. IPM, NRECA/EI Sulvador, Ji:ly 1989.,

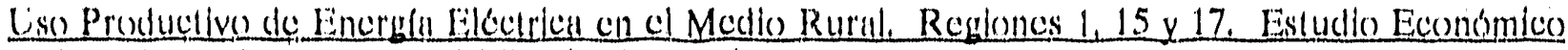
Y Financiero, IPM. NRECA/EI Salviador, July 198\%.

Mechanical Design for Overhead Distribution Lines. R.EA Bulletin 160)-2, Rural Electrificution Administration, United States Department of' Agriculture.

Nilional Electricul Sulcty Code.

Nantional Electrical Code. 


\section{APPENDIX 3: S'IATEMEN'T OF WORK FOR EVALUATION 'TEAM}

The evaluation will consist of four basic tasks. These will include the following:

1. Review ol project documentation including lechnical reports generated by NRECA staff and consulants relating directly to project implementation.

2. Interview key personncl. This lask will include interviews with personnal jointly selected by NRECA/Guatemala stalf' with the evaluation team. It should include both utility and non-utility counterparts, and other parlicipating institutions, as appropriate.

3. Assess selected activitics of the CARES program, as identilied by evaluation team, ROCAP and NRECA. This process will follow a technical orientation, the purpose of which will be to provide substantive input to directions and trends in line activitics.

4. Report conclusions and recommendations.

\section{Revicw of Project Dekcuments}

Project documents often provide a synopsis of the trends of activities, diflileulties encountered and overeome, and critical issues identilied and addressed throughout the eourse of a project. Although many documents have been routincly sent to ORNL for revicw, many of the activity reports, lravel reports, and consultant reports have not been provided. These documents may provide the evaluation team with a sound background to begin interviews with personnel in participating agencies for each respective host country.

Documents to be revicwed should include (at a minimum) the following:

1. Project Cooperative Agreement (no, 596-(0146-A-(0)-7(022-0(0)

2. Annual work plans.

3. Quarterly and annual reports.

4. ORNL monitoring reports.

5. Consulting reports.

6. Project activily reports (status and plans).

7. Project trip reports.

8. Publicallions produced as a result of project activities.

9. Other reports and decuments, as identilied by ROCAP and NRECA. 


\section{Interview Key Personnel}

To develop a sound understanding of the project's mission and accomplishments, the evaluation team will need to interview a wide range of personnel from various agencies that have collaborated and contributed to these activities. In some cases, this will require travel to other countries served by the project, including, for example, Belize, Honduras, El Salvador and Costa Rica.

A list of appropriate individuals to be interviewed will be drafted on the first few days of the evaluation time table. The list will consist of key subcontractors; USAID missions in participating countries; primary collaborative agencies (e.g., INDE, BEB, CONELECTRICAS, ENEE, etc.); and others, as deemed appropriate.

The interviews will focus on technical, institutional support, and training issues, as they relate to project implementation. Impressions of the project's direction, methodology, timeliness, responsiveness, and effectiveness will be solicited. The evaluation team will pay particular attention to the perceived needs of collaborating agencies, and the extent to which the project is currently addressing these needs, or will do in future project years.

\section{Assessment of Selected CARES Activities}

In addition to conducting interviews with selected agencies and individuals connected with the project, the evaluation team will assess selected activities undertaken by project staff. Activities will be reviewed within the context of project development goals and themes, such as enhancement of economic productivity; environmental preservation and security; institutional development. Specific activities to be reviewed will be selected jointly by ROCAP, NRECA and the evaluation team, and may include (but will not necessarily be limited to) the following:

1. Productive uses (Belize suggested).

2. Irrigation rate study (Honduras).

3. Training activities (Regional).

4. Demand assessment model update (El Salvador).

5 Surplus equipment (Guatemala).

6. Transformer evaluation (Regional).

7. Reforestation initiative (Regional).

Each of the above topics will be reviewed for technical direction, progress, and the degree to which counterpart agencies have participated in each respective activity. Project management will be assessed, as related to achievement of milestones, and as related to quality of work performed to date. 


\section{Composition of Evaluation Tcam}

The evaluation team will consist of three specialists with experience in rural development issues, as they pertain to energy use and electrification in developing countries. The team members will by necessity have a working knowledge of Spanish, and should be familiar with energy issues, and in particular, power sector issue in Central America.

The team will be composed to provide skills and experience in project management; distribution engineering; economic analysis; rural development; small, isolated generation; and training programs. Ideally, the team will be composed with at least one individual with substantial work experience in Central America; at least one engineer; at least one economist; and an individual with in-residence experience managing an A.I.D.-funded development project.

The team personnel may include individuals from ORNL, but will include at least one individual not employed full time by ORNL. All individuals will be required to become familiar with the CARES project by a thorough review of descriptive project documents prior to arrival in Guatemala.

The evaluation will be scheduled to be conducted over a three week period, to be agreedupon jointly by ROCAP, NRECA and ORNL. It is suggested to conduct the evaluation in March, 1990.

Resumes of candidates for the evaluation team will be forwarded to ROCAP for approval no later than 20 working days prior to the scheduled evaluation date. NRECA will be consulted regarding team composition prior to submission of resumes to ROCAP.

\section{Reporting}

A draft written report will be provided to ROCAP and NRECA prior to the evaluation team's departure. The report will be written to provide sufficient time to allow the main findings and recommendations to be discussed with ROCAP and NRECA prior to departure.

The report will include an executive summary, including findings and recommendations. The body of the report will provide a summary of project activities and institutions involved with the project; the activities undertaken to date, as well as an outline of planned activities; a section describing the review the tangible and intangible benefits to electric power institutions collaborating with the project, including a summary of relevant comments made by key individuals interviewed by the evaluation team; a section describing the technical review of project activities; and a section summarizing conclusions and recommendation. The evaluation report will be no longer than 40 double spaced, typed pages, exclusive of table of contents and the executive summary.

A final report will be due no later than 15 working days after written comments have been delivered to ORNL by ROCAP and/or NRECA. 

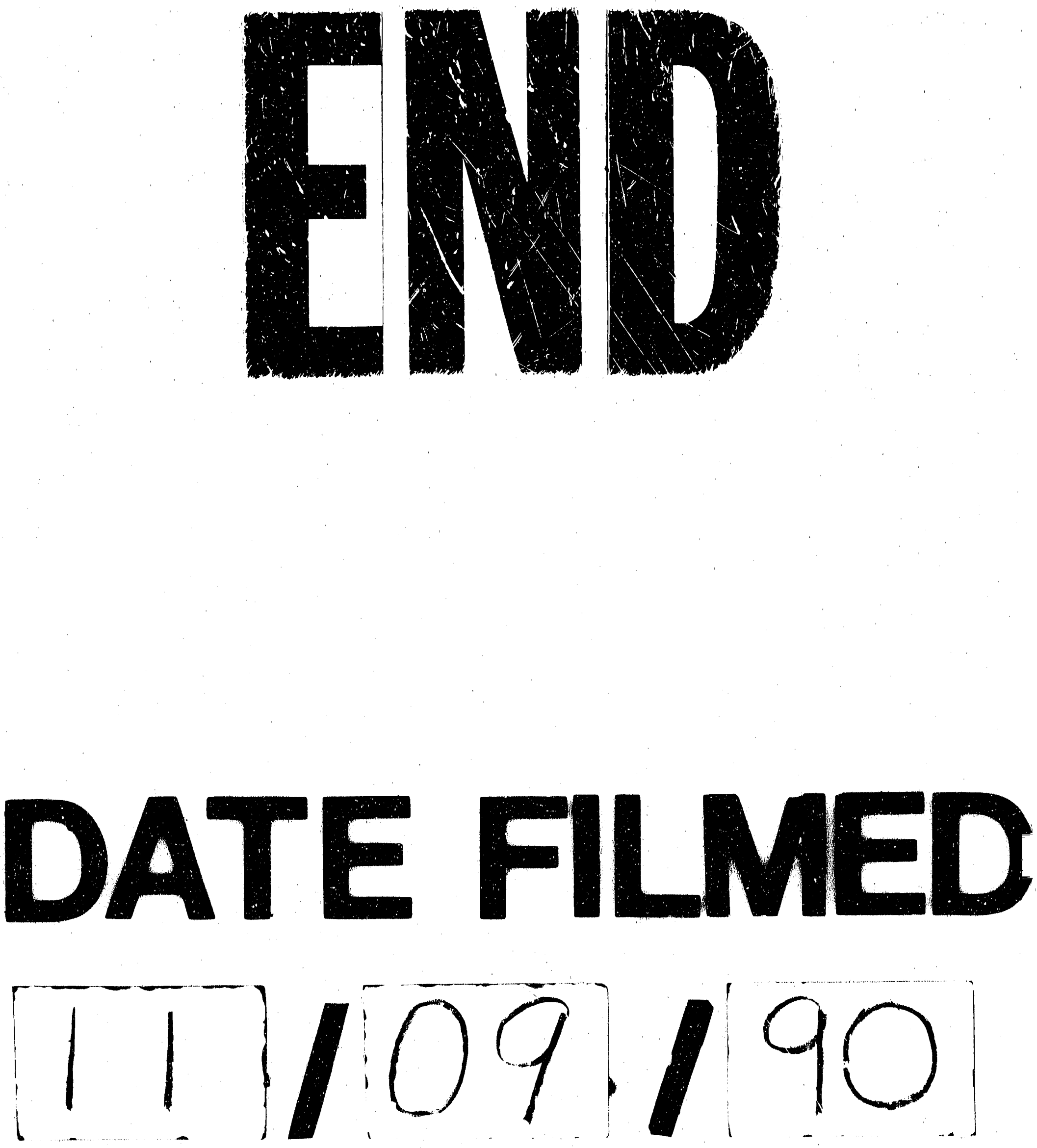
